\title{
16. SEISMIC-TO-WELL CORRELATION OF SEISMIC UNCONFORMITIES AT LEG 150 CONTINENTAL SLOPE SITES ${ }^{1}$
}

\author{
Juan M. Lorenzo ${ }^{2}$ and Stephen P. Hesselbo ${ }^{3}$
}

\begin{abstract}
Seismic-to-well correlation at Ocean Drilling Program (ODP) continental slope Sites 902, 903, 904, and 906 identifies 19 Pleistocene-Eocene unconformable surfaces and reflectors. Seismic features on 120-channel, tuned, air-gun seismic data are tied to borehole depths via one-dimensional synthetic seismogram models. Reprocessed migrated seismic profiles along Maurice Ewing Lines 1005 and 1027 reveal clear images of two middle Miocene canyon-cutting surfaces and Pleistocene slumpbounding unconformities. At Site 904, good-quality compressional-wave velocity and density values allow models to match seismic facies. A high-amplitude continuous seismic facies between Miocene unconformities $q$ and $w$ can be attributed to distal toe-of-delta clinoforms containing alternating glauconite-rich and -poor sedimentary facies. A seaward-thinning Oligocene interval downlaps the upper Oligocene/upper Eocene, producing reflectors resolvable only through ties to biostratigraphic and lithologic borehole data. A silica-indurated diagenetic front within the middle Eocene produces reflectors that do not have chronostratigraphic significance and can mislead sequence stratigraphic interpretations.
\end{abstract}

\section{INTRODUCTION}

During June and July 1993, Ocean Drilling Program (ODP) Leg 150 drilled four sites on the New Jersey (U.S.A.) continental slope, all within $12 \mathrm{~km}$ of the continental shelf/slope break (Fig. 1). Despite several previous coring programs, sampling of the Tertiary sedimentary record remained relatively incomplete before Leg 150 drilling. Indeed, most of the previous wells drilled nearby on the upper slope (COST B-3; Scholle, 1980), middle slope (ASP 14 and 15; Poag, 1985), and lower continental slope (Deep Sea Drilling Project [DSDP] Leg 95; Poag, Watts, et al., 1987) had failed to sample the upper Miocene-Holocene section. These four closely spaced wells (Sites 902, 903, 904, and 906; Fig. 2) sampled the first kilometer of a lower Eocene-Holocene section, producing the most continuous upper Oligocene-Holocene section in the area to date. This section is part of a $>15-\mathrm{km}$ thick wedge of sediments on the continental margin that overlies thinned continental crust (LASE, 1986).

As one of its principal aims, Leg 150 sought to date several major Oligocene-Holocene hiatuses and test their origin against glacioeustatic isotopic indicators (Miller et al., 1991) and other inferred eustatic curves (Haq et al., 1987). Cenozoic history on this slope is, in large part, represented by hiatuses rather than depositional sequences (Greenlee and Moore, 1988). Repeated erosional events have affected the slope since the Paleogene (e.g., Tucholke and Mountain, 1979; Scholle, 1980; Poag, Watts, et al., 1987; Mountain, 1987), producing a discontinuous stratigraphic architecture. Howev$\mathrm{er}$, the regional significance of these boundaries rests on the precision and accuracy of seismic-to-well correlations. Herein, we attempt to test previous shipboard seismic-to-well correlations using (1) new synthetic seismogram models based on shipboard laboratory physical properties data and (2) migrated seismic reflection profiles. Ship-

'Mountain, G.S., Miller, K.G., Blum, P., Poag, C.W., and Twichell, D.C. (Eds.), 1996. Proc. ODP, Sci. Results, 150: College Station, TX (Ocean Drilling Program).

${ }^{2}$ Department of Geology and Geophysics, Louisiana State University, Baton Rouge, LA 70803-4101, U.S.A. juan@tellus.geol.Isu.edu

${ }^{3}$ Department of Earth Sciences, University of Oxford, Parks Road, Oxford OXI 3PR, United Kingdom. board laboratory physical properties data compensate for those cases in which downhole logging suffers from poor borehole conditions and seismic reprocessing improves the resolution of sequence stratigraphic interpretations by removing noise from the data. These new, higher resolution correlations permit a reevaluation of seismic sequence boundaries in terms of facies and sedimentary processes.

At Sites 904 and 906, where downhole logging data were degraded by poor borehole conditions, synthetic seismograms constructed from shipboard laboratory physical properties have the potential of independently testing and improving time-depth correlations. Seismic-well correlations aboard Leg 150 were calculated from an empirical relation that best fit two-way traveltimes of prominent reflectors vs. depth to the assumed source of these reflections at Site 902 (Mountain, Miller, Blum, et al., 1994). Synthetic seismogram models have the advantage of not requiring this a priori knowledge of seismic-well ties.

\section{SEISMIC REFLECTION DATA}

To conduct seismic-to-well correlations, we used multichannel seismic reflection data instead of single-channel data because they contained less noise and permitted a better resolution of stratigraphic features. In November 1990, before Leg 150, Maurice Ewing cruise 9009 collected air-gun, multichannel data near Leg 150 sites along Lines 1005 (Fig. 3) and 1027 (Fig. 4). These profiles have better resolution than any previous multichannel data set collected in the area, and they have been carefully stacked and filtered to preserve shallow fine-scale features (Mountain et al., 1994b; Mountain, Miller, Blum, et al., 1994). Nevertheless, this and any subsequent digital processing has the affect of removing true-amplitude information from the multichannel data and making correlations with the well data less robust.

Under ideal conditions, stacking in multichannel data enhances the signal-to-noise ratio by a factor equal to the square root of the number of channels (Mayne, 1962; Robinson, 1970; Sengbush, 1983). As the pre-cruise seismic data has 120 channels, the signal-tonoise ratio can be enhanced by a factor of 11 over single-channel data. The single-channel data is usually digitally recorded at a higher sampling rate $(1 \mathrm{~ms})$ than the multichannel data $(2 \mathrm{~ms})$ and can therefore capture higher frequency signals and allow better resolution. 
Figure 1. Bathymetric maps of portions of the New Jersey (U.S.) continental margin; isobaths in meters (curved solid lines). Inset at top left shows the position of the Leg 150 site area (small gray box) on the continental slope and east of Atlantic City. Small gray box also shown enlarged below as an open box, here and in Figure 2. Open box area contains Sites 902 through 906 (solid circles) and Continental Offshore Stratigraphic Test well B-3 (COST B-3) (open circle with cross) (Scholle, 1980). Seismic profiles interpreted in text (Mountain et al., 1994b; Mountain, Miller, Blum, et al., 1994) were collected along portions of Maurice Ewing 9009 ship tracks 1005 and 1027 (thin straight lines). Site 905 on the continental rise is not examined in this paper.

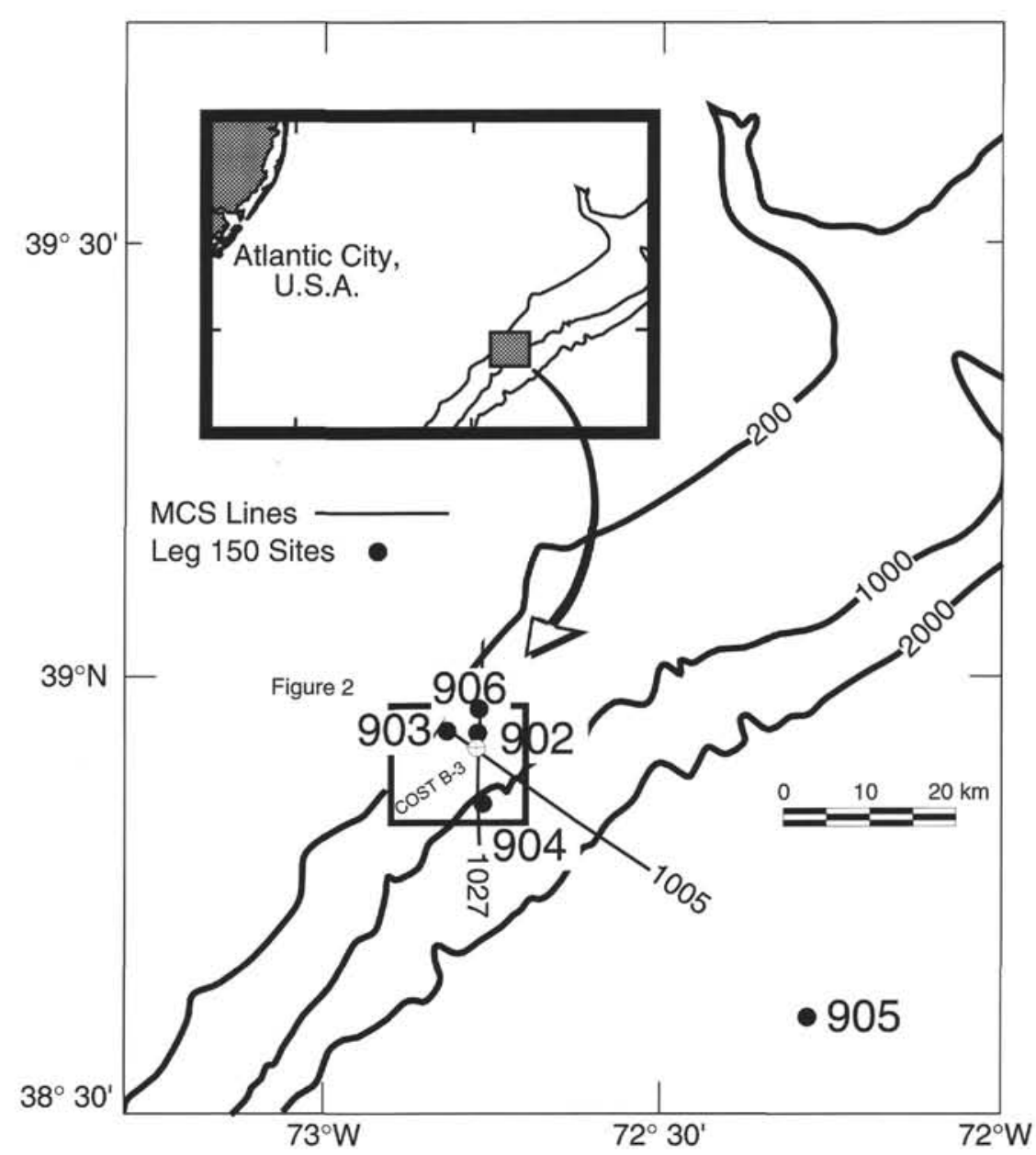

\section{KEY UNCONFORMITIES AND REFLECTORS}

However, vertical resolution is better in the multichannel seismic data because individual horizon reflections are less degraded by "ghosts"- seismic pulses produced from reflections at the sea-surface near the seismic sources and receivers (Parkes and Hatton, 1986). During Leg 150, three single-channel, pre-site, water-gun seismic surveys were conducted to help position wells for drilling in difficult, laterally variable stratigraphy, but these were not used for well correlation. The pre-site single-channel surveys did not minimize ghosts (Mountain et al., 1994a) as well as the multichannel survey because the towing depths of the streamer and water guns could not be adjusted as precisely.

After attempting constant velocity migration at varying velocities, we found that we were able to enhance the multichannel data by employing a value of $\sim 1800 \mathrm{~m} / \mathrm{s}$ and displaying results with a vertical exaggeration of $\sim 8$ (for a water velocity of $1500 \mathrm{~m} / \mathrm{s}$ ). Previous workers who used earlier versions of these seismic displays at a smaller vertical exaggeration ( 4) (Mountain, Miller, Blum, et al., 1994; G.S. Mountain, K.G. Miller, and N.C. Blick, unpubl. data, 1990) were not always able to clearly trace all important seismic sequence stratigraphic surfaces. A velocity of $1800 \mathrm{~m} / \mathrm{s}$ exceeds the average calculated interval velocity (Mountain, Miller, Blum, et al., 1994) in the zone from 400 to 500 mbsf. Constant velocity migration is a simple technique that minimizes the interference effect of both seafloor and subseafloor diffractions. In general, migration does not significantly affect the data traces used for seismic-to-well correlations; furthermore, it simplifies the interpretation of steeply dipping, unconformable, subseafloor surfaces.
Enhanced processing techniques of migration and redisplay produce high-resolution seismic profiles throughout the ODP drilling sites (Figs. 3, 4). We identified 19 reflectors and unconformable surfaces based on the seismic data. Unconformities create a discordant relationship between overlying and underlying reflectors, but they do not always produce good reflectors (Mitchum et al., 1977). For example, $1 \mathrm{~km}$ south of Site $906, \mathrm{q}$ is interpreted to be a buried canyon wall, but it does not return an observable reflection. We can trace $q$ along the abrupt reflector terminations that we assume abut the canyon wall. In this paper, we used a new set of alphanumeric names for our reflectors and unconformities ("a" through " $\mathrm{z} 2$ ") because they do not all agree exactly with previous interpretations. A few reflectors $\mathrm{g}$, $\mathrm{h}, \mathrm{i}, l 2, l 3$, and w could not be interpreted in this paper from the seismic data alone but were tentatively interpreted as unconformities on board Leg 150 from a more regional seismic data set and are included for comparison (Mountain, Miller, Blum, et al., 1994). Table 1 gives our new names and the equivalent names designated by other workers, together with the estimated position of each surface within the well in meters below seafloor (mbsf) where Sites 902, 903, 904, and 906 are projected onto the seismic line (Fig. 2) at given seismic trace numbers (common-depth points [CDPs]).

Erosion by present-day submarine canyons and mass-wasting processes commonly interrupt the lateral continuity of the shallow seismic reflectors. We were not able to correlate confidently any of the shallow, intra-Pleistocene, unconformable surfaces (a, d, and e) 


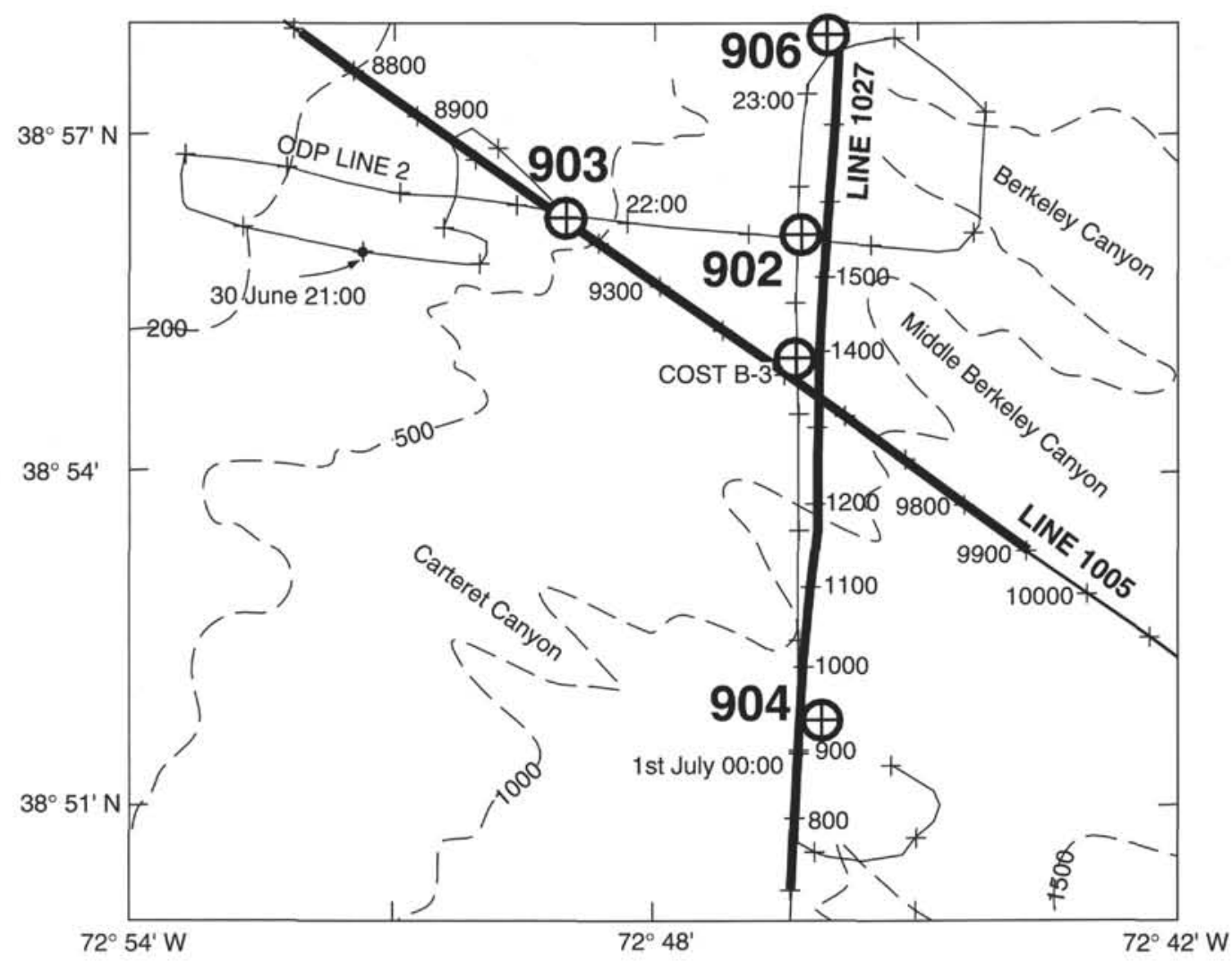

Figure 2. Enlarged bathymetric map of New Jersey continental slope shown in Figure 1; isobaths in meters (dashed lines). Leg 150 Sites $902,903,904$, and 906 and the COST-B3 well site are shown adjacent to ship tracks (solid lines). Thin continuous line marks the track of JOIDES Resolution during water-gun, singlechannel, seismic, pre-site survey 2 (ODP Line 2 collected in 1993; Mountain, Miller, Blum, et al., 1994) and the tracks of Maurice Ewing tuned air-gun, multichannel, seismic, pre-cruise survey (Leg 9009, Lines 1027 and 1005, collected in 1990; Mountain, Miller, Blum, et al., 1994). Thick continuous lines highlight the position of seismic profiles interpreted in this paper and seen in Figures 3 and 4 .

and reflectors (b, c) at Site 902 with those at Site 903 (g, h, and i). Hence, shallow seismic event names at Sites 902 and 903 are different. Reflectors b, c, g, h, and $\mathrm{i}$ are not shown in the interpretations of Figures 3 and 4 because we cannot attach sequence stratigraphic significance to them. Future studies may establish clearer relationships between unconformities at different positions on the slope. Deeper and older surfaces such as $l$, $\mathrm{m}$ and $\mathrm{q}$ can be traced confidently between Sites 902, 904, and 906 along Line 1027 (Fig. 4) and Site 903 on the profile along Line 1005 (Fig. 3). We consider $l$ to be a major unconformity because it truncates reflectors along the length of Line 1005 .

Within the middle Miocene portion of the seismic profile on Line 1027 (Fig. 4), unconformities $\mathrm{m}$ and $\mathrm{q}$ trace buried submarine incisions of notable relief. Unconformity $m$ was penetrated at DSDP Site 612 (Poag and Mountain, 1987) and is probably equivalent to Miller et al.'s (1987) M1 unconformity, a middle-late Miocene canyon surface formed in response to a global sea-level lowering. A canyon-cutting interpretation is consistent with a 100 -ms-deep incision into underlying reflectors formed by m near Site 906 (Fig. 4).

We estimate that the incision produced by q near Site 906 is 230 $\mathrm{m}$ deep under the present-day continental slope (Fig. 4). We chose surface q carefully to divide underlying truncated reflectors from overlying continuous or onlapping reflectors (e.g., near Sites 906 and 904). Reflectors can- 1 and can- 2 lie within the canyon created by $q$ and correlate to the top and bottom of a canyon-fill, sand-rich unit above unconformity q. Migration does not eliminate the arcuate nature of can-1 and can-2 (Fig. 4). Therefore, these reflectors probably represent a true contorted acoustic interface that may be interpreted as either (1) partly incised surfaces with no underlying acoustic layering or (2) true folded (slumped?) bedding. The southern shoulder of the canyon cut by $\mathrm{q}$ is onlapped by two prominent parallel reflectors at about $1.5 \mathrm{~s}$ two-way traveltime. Unconformity $\mathrm{q}$ is also associated with the base of a small, buried channel at about CDP 1050 just north of Site 904.

Surface y separates units of contrasting sediment type. Across y, pelagic upper Eocene chalks are separated by an 5- to 10-m.y. time gap from overlying upper Oligocene hemipelagic siliciclastic sediments. This change in sediment facies is attributable to a major paleoenvironmental change from subtropical conditions in the Eocene to Oligocene "ice-house" conditions (Fischer, 1984; Schlee et al., 1988). Reflector $\mathrm{zl}$ is correlated to the unconformable upper/middle Eocene boundary, but it does not display any unconformable relationship in the seismic section. Reflector $\mathrm{z} 2$ is produced at a diagenetic front that separates semi-indurated chalks from underlying porcellanitic chalks. This diagenetic front is a diachronous interface that occurs throughout the western North Atlantic and was recognized by DSDP Legs 43 (Tucholke and Vogt, 1979) and 95 (Poag, Watts, et al., 1987) as reflector $\mathrm{A}^{\mathrm{c}}$.

\section{SYNTHETIC SEISMOGRAMS Data}

Density and compressional-wave velocity are the two essential physical properties used in synthetic seismogram modeling (Figs. 58). Good hole conditions prevailed at Holes 904A (Fig. 7) and 906A 


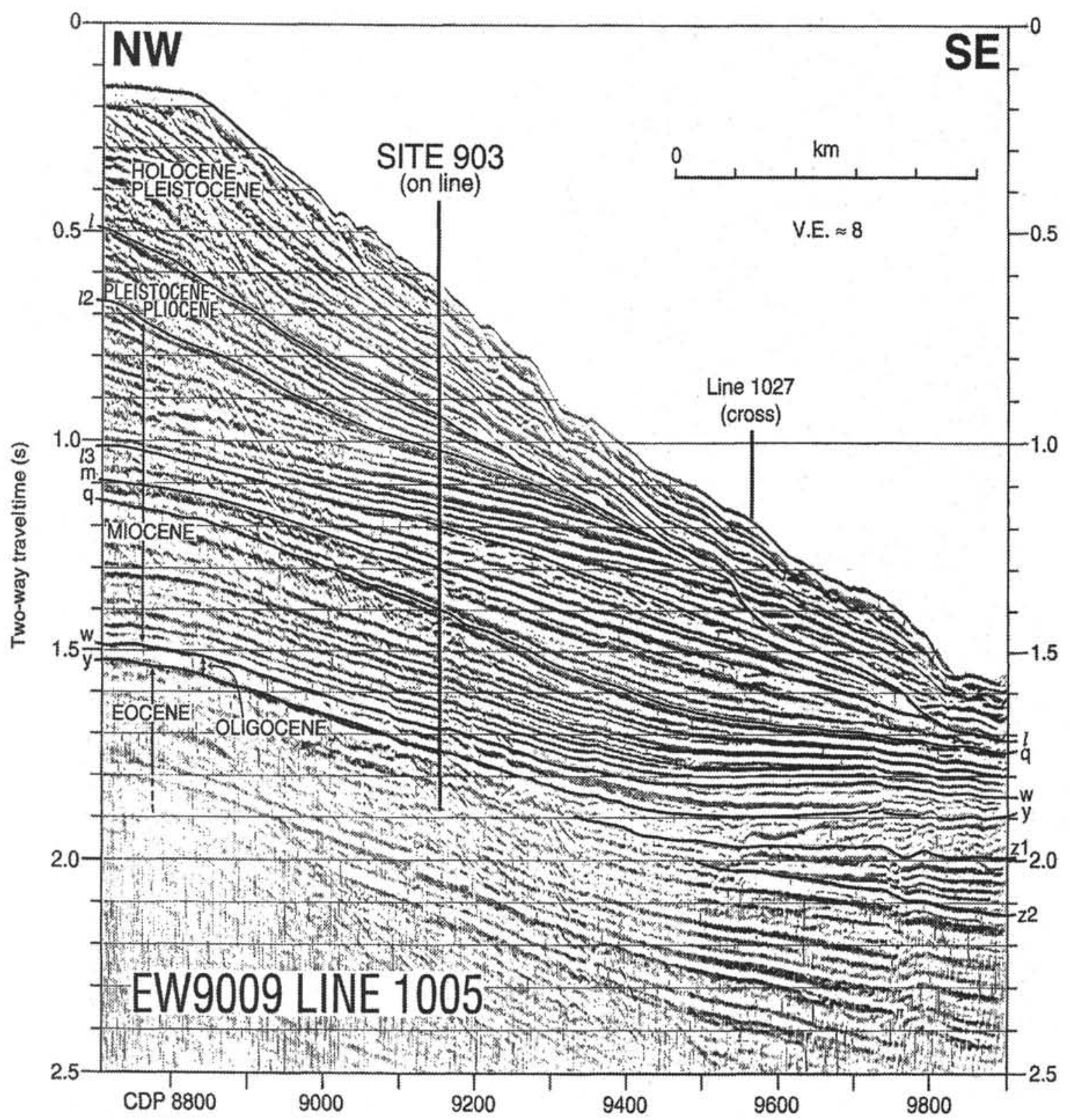

Figure 3. Local sequence stratigraphic line interpretation superimposed on migrated seismic profile. Projected well sites, online well locations, and intersection with seismic Line 1027 (Fig. 4) are marked with vertical lines to indicate the vertical extent of core sampling or downhole logging. Letters mark (1) seismic unconformities $(l, \mathrm{~m}, \mathrm{q})$ interpreted using only data along Lines 1005 and 1027 , and (2) reflectors and surfaces of sequence stratigraphic significance $(l 2, l 3$, y, $\mathrm{z1}, \mathrm{z} 2$ ), either adapted from Mountain, Miller, Blum, et al. (1994: 12, 13, w) or interpreted with the aid of well data (y, z1, z2). V.E. = vertical exaggeration.

(Fig. 8) and, except for small intervals with poor downhole density measurements, shipboard laboratory and downhole data sets exhibit similar trends and values. Poor borehole conditions led to downhole data that was unreliable for synthetic seismogram modeling at Hole 902D (Fig. 5) or suspect at Hole 903C (Fig. 6).

\section{Downhole Compressional-Wave Velocity and Density Data}

During Leg 150, compressional-wave velocities (sonic digital tool) and formation densities (high-temperature lithodensity tool) were logged regularly in the hole every $0.15 \mathrm{~m}$. These measurements had a minimum vertical resolution of $0.3 \mathrm{~m}$ (Mountain, Miller, Blum, et al., 1994).

Each downhole logging tool has a different sensitivity to the changes in borehole geometry (measured by the caliper tool). Unsta- ble hole conditions are responsible for variable-sized boreholes and large-diameter boreholes, both of which degrade downhole density estimates (Mountain, Miller, Blum, et al., 1994; Rider, 1986). Downhole velocity values are less sensitive to hole diameter variability. Even at Sites 904 and 906 (Figs. 7, 8), where the logging data are good, there were localized zones with poor downhole density values (e.g., 100- 200 mbsf at Hole 904A [Fig. 7], and 285- 300 and $\sim 370-380$ mbsf at Hole 906A, [Fig. 8]). In contrast, laboratory compressional-wave velocities and wet-bulk density values taken from core samples are unaffected by hole conditions.

If hole conditions are ideal, downhole physical properties logs can present distinct advantages over shipboard laboratory physical properties measurements because readings are made under in situ conditions and at regular intervals even through zones where core recovery may be poor. Good downhole velocity and density logs were gath- 


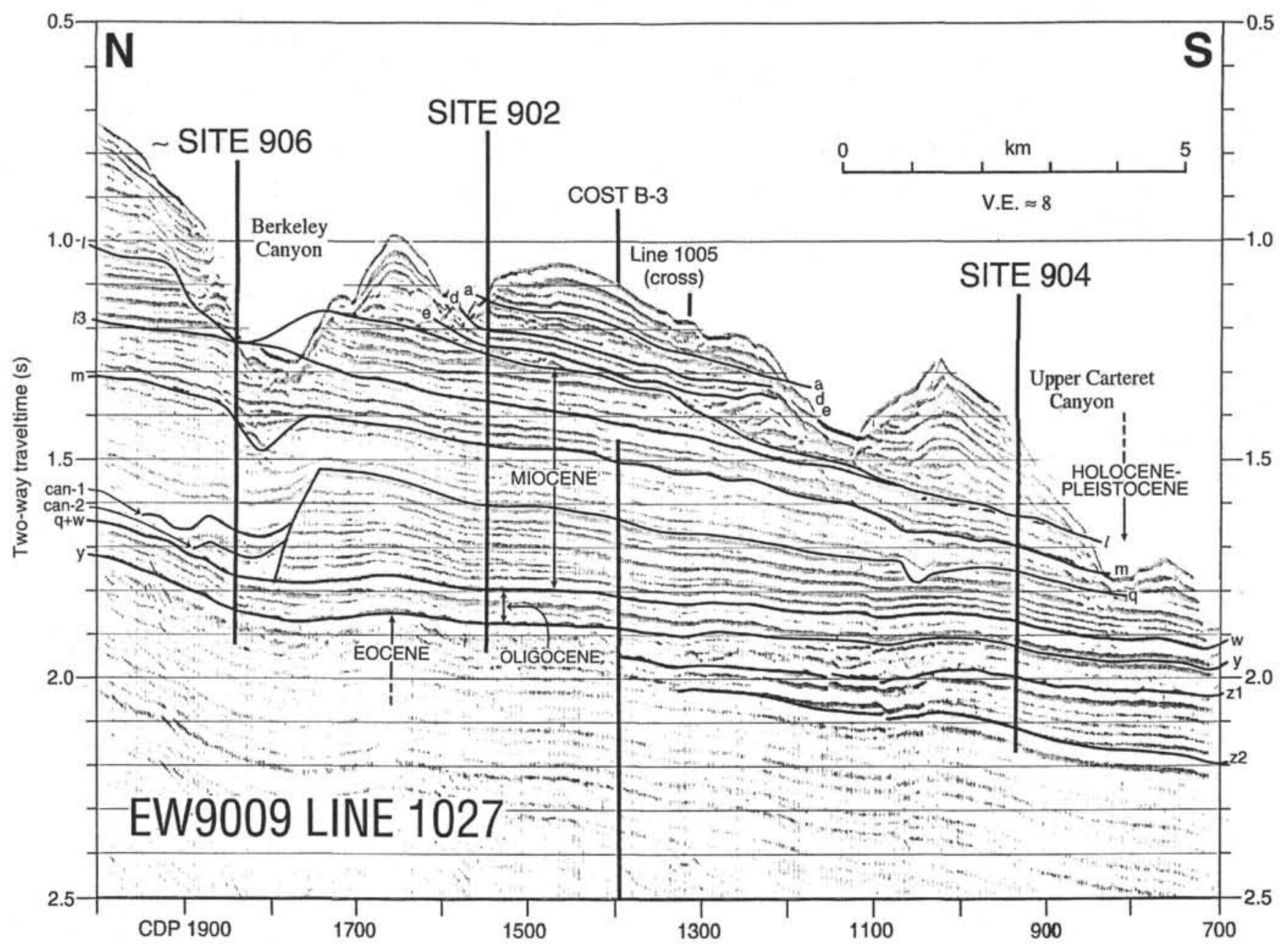

Figure 4. Sequence stratigraphic line interpretation superimposed on migrated seismic profile. Projections of well sites, online well locations, and intersection with seismic Line 1005 (Fig. 3) are marked with vertical lines. Letters mark (1) seismic unconformities (a, d, e, m, q) interpreted from seismic data along Lines 1005 and 1027, and (2) reflectors and surfaces of sequence stratigraphic significance either adapted from Mountain, Miller, Blum, et al. (1994: l3, w) or interpreted with the aid of well data $(y, z 1, z 2)$. V.E. = vertical exaggeration.

ered at Site 906 throughout the submarine channel infill (lithologic Unit V), whereas in the same unit, only $2 \%$ of the central cores (150$906 \mathrm{~A}-43 \mathrm{X}$ and $44 \mathrm{X}$ ) were available for laboratory physical properties sampling.

\section{Shipboard Compressional-Wave Velocity and Density Data}

All the shipboard laboratory compressional-wave velocity and wet-bulk density data used in synthetic seismogram modeling were hand-sampled. Measurements were taken, on average, every $3 \mathrm{~m}$ throughout Leg 150. A 3-m sampling interval is better than the resolution of the available reflection seismic data and assures a sufficiently dense and accurate coverage of all sediment and rock types. Resampling at this small interval preserves much of the original detail and facilitates model calculations. Velocities were measured using a Hamilton Frame velocimeter (Edgar, Saunders, et al., 1973) or Digital Sonic Velocity Tool (Mayer, Pisias, Janacek, et al., 1992), whereas wet-bulk densities were estimated using wet-sample masses and volumes.

During downhole logging, the upper 70-100 $\mathrm{m}$ of the hole is usually occupied and stabilized by a drill pipe through which the sonic and lithodensity tools cannot take meaningful measurements. In the shallowest portions of the boreholes, only laboratory velocity and density estimates can be used for synthetic seismogram modeling. Core recovery in the upper $100 \mathrm{~m}$ of sediments during Leg 150 was high, on average $\sim 88 \%$. Thus, these shallow sections produced excellent physical properties records, including density values.

Shipboard physical properties measurements are subject to errors caused by sediment disturbance either during drilling or transport to the surface. In general, when brought to the surface, sediment experiences an intrinsic rebound that increases porosity above in situ values (Hamilton, 1976). Cores also experience the release of volatile gases that create expansion voids. It is possible that microfractures created in the samples from Holes 902D and 903C during the expansion (i.e., to lower ambient pressures) of volatile gas as the core was brought to the surface attenuated the shipboard laboratory velocity signal to a point that it did not yield any reliable velocity measurements at these sites. These effects on shipboard laboratory compressional-wave velocity and wet-bulk density values appear to be a source for potential errors in calculating the synthetic seismograms.

Downhole compressional-wave velocities and density values, by contrast, are free of rebound effects and core gas expansion; they should provide more accurate compressional-wave velocity and formation density values. Density values should decrease as a result of sediment rebound. Nevertheless, a comparison of the good-quality downhole and shipboard laboratory physical properties measure- 


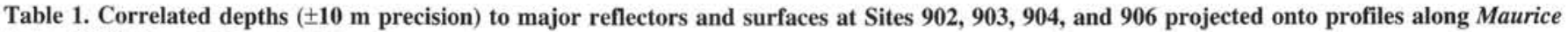
Ewing 9009 Lines 1005 and 1027.

\begin{tabular}{|c|c|c|c|c|c|c|c|}
\hline Site & & & & 903 & 906 & 902 & 904 \\
\hline Line & & & & 1005 & 1027 & 1027 & 1027 \\
\hline CDP & & & & 9150 & 1840 & 1546 & 935 \\
\hline \multirow[t]{3}{*}{ Ages } & $\begin{array}{l}\text { This } \\
\text { paper }\end{array}$ & Interpretation & $\begin{array}{c}\text { Onboard } \\
\text { name }\end{array}$ & $\begin{array}{l}\text { Depth } \\
\text { (mbsf) }\end{array}$ & $\begin{array}{l}\text { Depth } \\
\text { (mbsf) }\end{array}$ & $\begin{array}{l}\text { Depth } \\
\text { (mbsf) }\end{array}$ & $\begin{array}{l}\text { Depth } \\
\text { (mbsf) }\end{array}$ \\
\hline & a & $\mathrm{U}$ & & & & $20(+)$ & \\
\hline & $\mathrm{b}$ & None/reflector & & & & $25(-)$ & \\
\hline \multirow[t]{2}{*}{ Holocene } & c & None/reflector & p2 & & & $45(-)$ & \\
\hline & d & U & p3 & & & $80(-)$ & \\
\hline \multirow[t]{3}{*}{ to } & e & $\mathrm{U}$ & $\mathrm{p} 4$ & & & $115(-)$ & \\
\hline & $g$ & & pl & $80(-)$ & & & \\
\hline & h̆ & & $\mathrm{p} 2$ & $130(-)$ & & & \\
\hline Pleistocene & $\mathrm{i}$ & & $\mathrm{p} 3$ & $205(-)$ & & & \\
\hline \multirow[t]{5}{*}{$-?-?-$} & 1 & $\mathrm{U}$ & $\mathrm{p} 5 / \mathrm{m} 0.5$ (red) $* / \mathrm{m} 0.7$ & (p5) $280(+)$ & $40(-)$ & $(\mathrm{m} 0.5) 130(-)$ & $(\mathrm{m0.7}) 105(+)$ \\
\hline & 12 & $\mathrm{U}$ & p6 & $360(+)$ & & & \\
\hline & 13 & $\mathrm{U}$ & $\mathrm{m} 0.7$ & $545(+)$ & $40(-)$ & $210(+)$ & \\
\hline & $\mathrm{m}$ & $\mathrm{U}$ & $\mathrm{ml}, \operatorname{tuscan} * / \mathrm{ml} .5$ & $(\mathrm{ml} .5) 650(-)$ & $(\mathrm{ml} .5) 170(-)$ & $(\mathrm{m} 1.5)^{* *}$ & $(\mathrm{ml}) 162(-)$ \\
\hline & can-1 (-) & Canyon & canyon-1 & & $380(-)$ & & \\
\hline \multirow[t]{3}{*}{ Miocene } & $\operatorname{can}-2(+)$ & Fill & canyon- 2 & & $420(+)$ & & \\
\hline & $\mathrm{q}$ & $\mathrm{U}$ & $\mathrm{m} 3$ ?, blue* & $720(+)$ & $475(-)$ & $* *$ & $210(+)$ \\
\hline & \multicolumn{4}{|c|}{ Oligocene } & $480(-)$ & & $300(-)$ \\
\hline \multirow{2}{*}{ upper Eocene } & $y$ & $\mathrm{U}+\mathrm{SDL}$ & ol, green $2^{*}$ & $1060(-)$ & 555 & $680(-)$ & $340(+)$ \\
\hline & $\mathrm{z} 1$ & $\mathrm{U}$ & el & & Below TD & Below TD & $415(-)$ \\
\hline middle Eocene & $\mathrm{z} 2$ & Diagenetic front & e2 & Below TD & & & $525(-)$ \\
\hline
\end{tabular}

Notes: $\mathrm{CDP}=$ common depth point traces, $\mathrm{U}=$ unconformity, $\mathrm{SDL}=$ surface of downlap, $\mathrm{ND}=$ no data, and $\mathrm{TD}=$ total depth. Onboard descriptions of reflectors (Mountain, Miller. Blum, et al., 1994) are shown in parentheses next to estimated borehole depth. Reflectors are picked at either a negative/dilatational pulse (-, shaded) or a positive/compressional pulse $(+) .{ }^{*}=$ Name given by Greenlee et al. (1992) to a possibly equivalent shelf reflector or surface. ${ }^{* *}=$ Correlated depths cannot be estimated using synthetic seismograms alone.

ments at Holes 904A (Fig. 7) and 906A (Fig. 8) reveals that the density values are very similar in both data sets. Therefore, rebound effects are deemed minimal and were not considered during the modeling.

\section{Empirical Relation}

Shipboard laboratory compressional-wave velocity values were unavailable for Sites 902 and 903 . To compensate, we derived a set of estimated compressional-wave velocity values with an empirical relationship established between density and compressional-wave velocity values from the better quality data at Holes 904A and 906A. A second-order polynomial best fit to the data is:

$$
V_{p}(\rho)=3878.8-2876.3 \rho+918.26 \rho^{2}
$$

where $V_{p}$ is the compressional-wave velocity $(\mathrm{m} / \mathrm{s})$ estimated from the known measurements of density $\left(\rho, \mathrm{g} / \mathrm{cm}^{3}\right)$. Using this method, inaccuracies in the estimated velocity values accumulate traveltime errors, but the synthetic seismogram can still be useful for correlating portions of the borehole.

\section{Methods}

Seismic reflection data collected as a function of two-way traveltime below sea level can be correlated to biostratigraphic data collected as a function of depth in the well, using synthetic seismograms. We calculated synthetic seismograms using a one-dimensional linear filter approach (Peterson et al., 1955), in which a reflection coefficient model for the subsurface in the time domain is convolved with an estimate of the seismic source wavelet at normal incidence. Within the limits of vertical resolution (Widess, 1973; Sheriff, 1977), we assumed that reflections emanate from interfaces separating discrete geological units of differing acoustic impedance (density $\times$ compres- sional-wave velocity). Each reflection coefficient is a relative measure between the amplitudes of the original incident wave and the returning reflected wave, and is calculated for all model layer interfaces as a function of traveltime. Cumulative traveltimes using velocity logs are an alternative method of relating traveltime to depth (e.g., Poag, Watts, et al., 1987); however, this technique is limited because it does not incorporate subsurface density information.

In addition to providing acoustic traveltimes, the shape of the synthetic seismograms not only provides an approximate indication of the local reflection strength across an interface but also shows whether the acoustic impedance increases or decreases with depth. This method only approximately replicates the physical process of acoustic reflection because energy losses such as those caused by transmissivity, geometric spreading, attenuation, or the effects of internal reverberations are not computed. This method proves sufficient to replicate real seismic data, especially at Sites 904 and 906, where excellent physical properties data exist (laboratory wet-bulk density, downhole density, and compressional-wave velocity data).

We extracted a seismic-source wavelet before migration, using a portion of the seafloor reflection between 1.106 and $1.166 \mathrm{~s}$ two-way traveltime at CDP 1377, Line 1027 (Fig. 4). The source appeared both bubble-free and free of subseafloor reflections, and was chosen because it lay close to the drilling sites in a relatively flat part of the seafloor, where the possible effects of diffractions were minimized. Peak frequency for the source wavelet lies at about $40 \mathrm{~Hz}$. For a range of compressional-wave velocity in Leg 150 sediments of 1600-2000 $\mathrm{m} / \mathrm{s}$, the maximum range of vertical resolution, assuming $1 / 8$ to $1 / 4$ dominant wavelength (Sheriff, 1977; Widess, 1973), varies from about 5 to $12.5 \mathrm{~m}$. Thinner layers (e.g., $0.5 \mathrm{~m}$ ) can return a reflecting wave, but the top and bottom of such layers cannot be resolved.

Reflectivity coefficients vs. depth were calculated every $0.5 \mathrm{~m}$ at the same interval as the resampled compressional-wave velocity and density data. When the reflection coefficient series values were converted from values as a function of depth to values as a function of time by integrating traveltimes using velocity logs, the data were smoothed, but we confirmed that all the key correlatable features were preserved. 


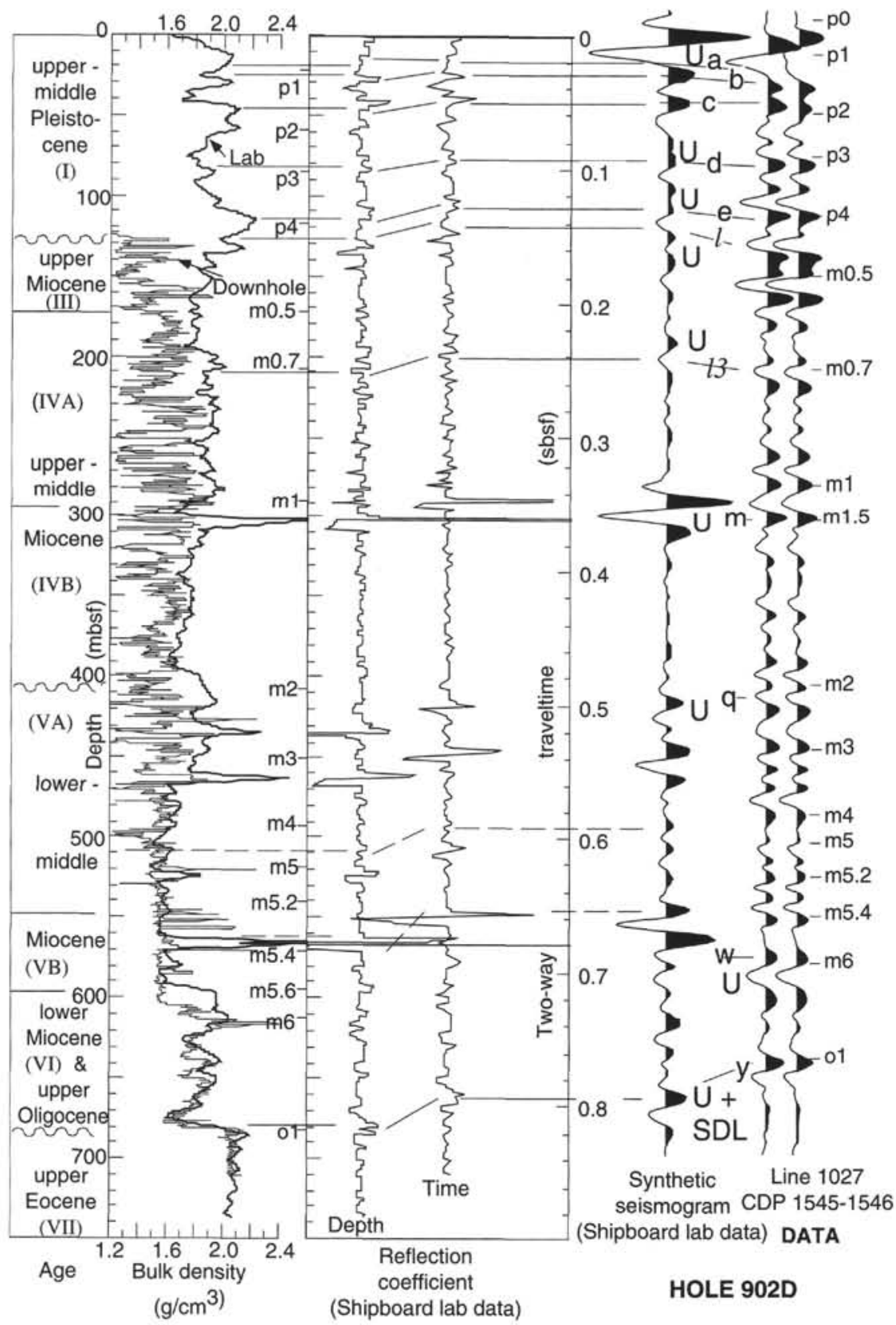

Figure 5. Surfaces and reflectors (a, b, c, d, e, l, l3, m, q, and y) in the seismic profile along Ew9009 Line 1027 nearest Site 902, matched to well depths, biostratigraphic ages, and lithologic units, expressed as roman numerals (Mountain, Miller, Blum, et al., 1994), through synthetic seismograms and reflection coefficients. The poor match to the synthetic seismogram prevents correlation of $\mathrm{m}(\mathrm{m} 1.5$ ? $)$ and $\mathrm{q}$ to borehole depths. Reflection coefficients vs. time (seconds below seafloor [sbsf]) and depth were derived from shipboard laboratory values of wet-bulk density (thick line) and compressional-wave velocity values, derived from an empirically derived relationship. The downhole formation density (thin line) is shown for comparison, but it was not used in calculating the synthetic seismogram. Interpretation of sequence stratigraphic surfaces: $\mathrm{U}=$ interpreted unconformable surface and SDL $=$ surface of downlap. Shipboard seismic picks and corresponding borehole correlations are indicated by letter names beside short horizontal ticks (Mountain, Miller, Blum, et al., 1994).

\section{CORRELATION CHARTS}

Ties between synthetic seismograms and well depths are achieved by using two series of reflection coefficients: those from the Ewing 9009 data and those from the synthetic seismograms. Reflectors recognized in traces of the Ewing 9009 seismic data are visually correlated with the model reflection coefficient series, expressed in twoway reflection traveltime. Then, the correlation is carried over to the model reflection coefficient series expressed as a function of borehole depth. Correlation lines in Figures 5 through 8 connect reflection coefficients in depth and time. Seismic-to-well correlation is limited by the interference effect of reflections from closely spaced boundaries. Dominant, isolated, high-amplitude reflectors can be easily traced back to a zone of large acoustic impedance contrast, but weaker reflectors may only be correlated approximately to a given interval within the borehole. Figure 9 summarizes the proposed ties between seismic picks and unconformities to lithology and ages. Final seis- mic-well correlation of ambiguous reflectors may be driven by particular stratigraphic models.

In the synthetic seismograms, the seafloor reflection that represents a case of increasing acoustic impedance with depth is chosen by convention at the center of the largest first shaded pulse. Seismic data are displayed using the same convention as the shipboard data (Mountain, Miller, Blum, et al., 1994) with negative (dilatational) pulses shaded. In the synthetic seismograms, all seafloor reflections produced from the shipboard laboratory physical properties data are strikingly large. Density and velocity measurements at the seafloor do not exist. Therefore, we applied the nearest reasonable values, always within a few meters of the seafloor. It remains a feasible task, albeit unnecessary for our immediate purposes, to adjust the seafloor velocities and densities in the models in order to reduce the amplitude of the seafloor reflections.

For ease of pattern-matching in all correlation charts (Figs. 5-8), the synthetic seismograms were shifted so that the center of the first 
Figure 6. Surfaces and reflectors (g, h, i, l, l2, $l 3, \mathrm{~m}$, $\mathrm{q}, \mathrm{w}$, and $\mathrm{y}$ ) in the seismic profile along Ew9009 Line 1005 nearest Site 903 matched to well depths, biostratigraphic ages, and lithologic units, expressed as roman numerals (Mountain, Miller, Blum, et al., 1994), through synthetic seismograms and reflection coefficients. The poor match to the synthetic seismogram prevents correlation of $\mathrm{w}$ to borehole depths. Reflection coefficients vs. time and depth were derived from shipboard laboratory values of wet-bulk density, compressional-wave velocity (thick lines), and downhole formation density and compressional-wave velocity values (thin line). The variable borehole diameter (mechanical caliper measurements) degrades the downhole data at $\sim 420$ mbsf to total depth and at places indicated by arrows ( $\sim 190$ and $\sim 200 \mathrm{mbsf})$. Interpretation of sequence stratigraphic surfaces: $\mathrm{U}=$ interpreted unconformable surface and SDL $=$ surface of downlap. Shipboard seismic picks and corresponding borehole correlations are indicated by letter names beside short horizontal ticks (Mountain, Miller, Blum, et al., 1994).

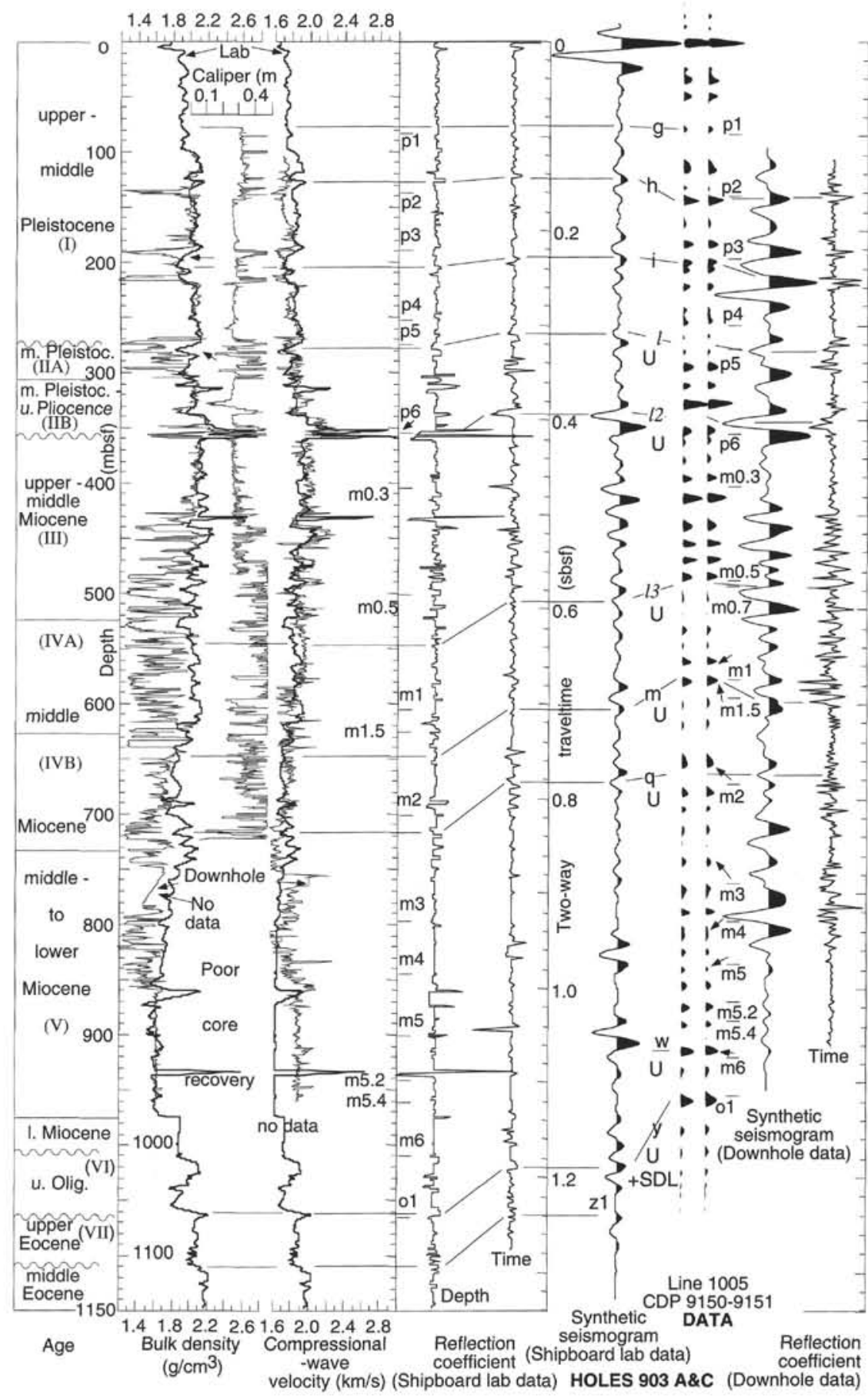

black pulse (seismic seafloor) was aligned with the borehole seafloor ( 0 mbsf). In this manner, interfaces below the seafloor across which there are relatively large increases in acoustic impedance should align with the centers of large pulses (black peaks). Synthetic seismograms created using downhole data from Holes 903A, 903C, 904A, and 906A (Figs. 6-8) yielded slightly earlier traveltimes to the deeper reflectors. Downhole data provided consistently greater compressional-wave velocities in the lower parts of the holes than in the shipboard laboratory data.

Amplitude values appear to vary considerably more in the synthetic seismogram traces than in the real data. Because the model and data amplitudes are not normalized, absolute amplitude values be- tween data and synthetic examples are not comparable and reflect the variability of the raw data. This effect is particularly pronounced in those downhole data sets collected under poor hole conditions as at Holes 903A and 903C (Fig. 6), within portions of Site 904 (Fig. 7) especially near q, and just below can-2 at Hole 906A (Fig. 8).

\section{Site 902}

Synthetic seismograms for Hole 902D (Fig. 5) were generated using only shipboard laboratory density estimates and empirically derived compressional-wave velocities because of the unusable results from the downhole and lab measurements. For parts of the borehole, 


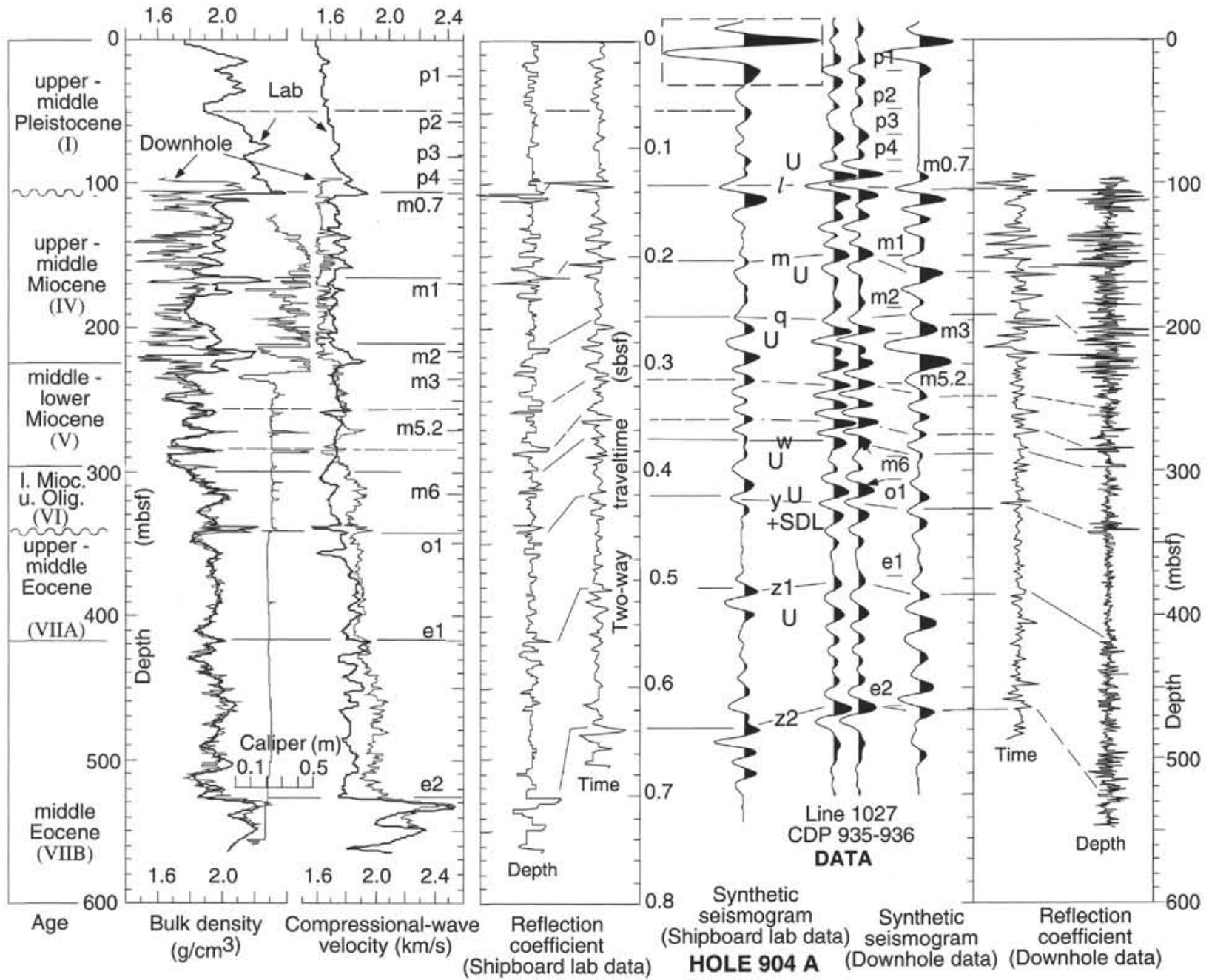

Figure 7. Surfaces and reflectors ( $l, \mathrm{~m}, \mathrm{q}, \mathrm{w}, \mathrm{y}, \mathrm{z1}$, and z2) in the seismic profile along Ew9009 Line 1027 nearest Site 904 matched to well depths, biostratigraphic ages, and lithologic units, expressed as roman numerals (Mountain, Miller, Blum, et al., 1994), through synthetic seismograms and reflection coefficients. Synthetic seismograms are calculated by convolving the estimate of a far-field source wavelet (dashed box) with reflection coefficients. Reflection coefficients vs. time and depth were derived from shipboard laboratory values of wet-bulk density, compressional-wave velocity (thick lines), and downhole formation density and compressional-wave velocity values (thin lines). The variable borehole diameter (caliper values) degrades the downhole data at $\sim 100$ to $\sim 200$ mbsf. Seismic traces 935 and 936 have been shifted to align to $l$. Some of the early arrivals in the seismic data may be contaminated with side-scattered diffractions. Interpretation of sequence stratigraphic surfaces: $U=$ interpreted unconformable surface and SDL $=$ surface of downlap. Shipboard seismic picks and corresponding borehole correlations are indicated by letter names beside short horizontal ticks (Mountain, Miller, Blum, et al., 1994).

poor shipboard physical property data limit the correlation of seismic surfaces to positions in the borehole. For this reason, unconformities $\mathrm{m}, \mathrm{q}$, and w cannot be correlated to the borehole. Nevertheless, surfaces and reflectors c, d, e, $l, l 3$, and y (Fig. 5) generally agree with previous onboard picks $\mathrm{p} 2, \mathrm{p} 3, \mathrm{p} 4, \mathrm{~m} 0.5$ and $\mathrm{m} 0.7, \mathrm{~m} 6$ and $\mathrm{o} 1$, respectively (Mountain, Miller, Blum, et al., 1994).

Initial synthetic seismograms produced with downhole data from Hole $902 \mathrm{C}$ and 902D were excluded from the correlation because they were contaminated by highly reverberatory noise in the upper half of the seismogram and overall did not contribute new information to the remaining correlation. This noise was caused by the variable borehole diameter resulting in short-spaced large downhole fluctuations of the calculated acoustic impedance.

Migration helps remove diffractive seismic noise and thus changes the character of the shallowest seismic data. Reflector picks made on unmigrated data may not line up with peaks in the reprocessed seismic data. At Site 902, reflectors p0 and p1 were defined ship- board from unmigrated data (Mountain, Miller, Blum, et al., 1994), but they are not apparent in the migrated seismic trace.

\section{Site 903}

At Hole 903C (Fig. 6), synthetic seismograms using shipboard data relied on empirically derived compressional-wave velocities and were used only to tentatively correlate reflectors $\mathrm{g}$, h, and $\mathrm{i}$ and surfaces $l, l 2, l 3, \mathrm{~m}, \mathrm{q}$, and $\mathrm{y}$ with borehole positions. Well conditions were generally poor and the resulting downhole compressional-wave velocity and density data are generally unreliable. To partly overcome this weakness in the data, we merged the better portions of the downhole compressional-wave and density data from Holes 903A and $903 \mathrm{C}$ to obtain as complete an estimate as possible of the physical properties for synthetic seismogram modeling. Some overall misalignment between mid-depth black peaks and shipboard reflector picks (Mountain, Miller, Blum, et al., 1994) are the result of employ- 


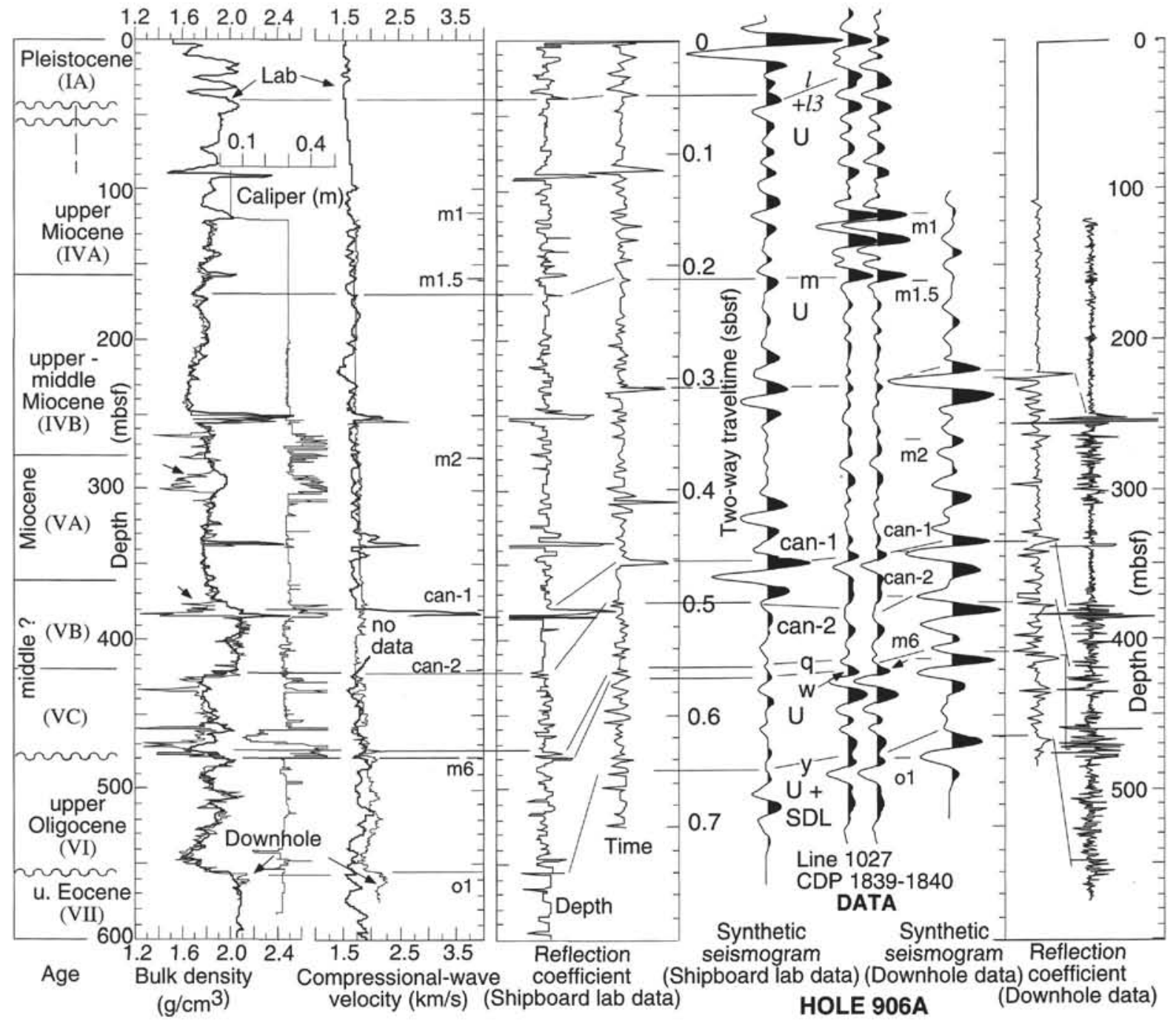

Figure 8. Surfaces and reflectors ( $(, 13, \mathrm{~m}, \mathrm{can}-1, \mathrm{can}-2, \mathrm{q}, \mathrm{w}$, and y) in the seismic profile along Ew9009 Line 1027 nearest Site 906 matched to well depths, biostratigraphic ages, and lithologic units, expressed as roman numerals (Mountain, Miller, Blum, et al., 1994), through synthetic seismograms and reflection coefficients. Reflection coefficients vs. time and depth were derived from shipboard laboratory values of wet-bulk density, compressional-wave velocity (thick lines), and downhole formation density and compressional-wave velocity values (thin lines). The variable borehole diameter (caliper values) degrades downhole data, as indicated by arrows at $\sim 290$ and $\sim 380$ mbsf. Shipboard seismic picks and corresponding borehole correlations are indicated by letter names beside short horizontal ticks (Mountain, Miller, Blum, et al., 1994).

ing traces adjacent to those used on board Leg 150. In these cases, the intended picks are marked by arrows (Fig. 6).

\section{Site 904}

At Site 904, shipboard physical properties are of excellent quality and result in the best synthetic seismograms of this correlation study. In Hole 904A (Fig. 7), high-amplitude seismic facies between $q$ and y at Site 904 and the polarity reversal at $l$ are well reproduced. At $l$, the downhole acoustic impedance contrast is negative because both the compressional-wave velocity and density drop below the Pleistocene/Miocene unconformity. The synthetic seismograms and seismic data are lined up to the data with reference to unconformity $l$ and not to the first major seafloor reflection peak (black). Diffraction events originating upslope near the seafloor were not sufficiently corrected by the constant-velocity migration and the true seafloor reflection was not recovered.

\section{Site 906}

At Site 906 (Fig. 8), $\mathrm{m}$ is correlated to a position in the borehole (170 mbsf) that is $10 \mathrm{~m}$ deeper than the nearest interpreted stratigraphic unconformity (m1.5; Mountain, Miller, Blum, et al., 1994). The cause of this difference may lie not with the modeling but with the estimated position of Site 906 on Line 1027. Site 906 does not lie in the plane of Line 1027 (Fig. 3) and could have intersected the canyon wall at a slightly shallower depth farther upsection.

\section{CORRELATION WITH SEISMIC DATA}

Pleistocene Surfaces a, d, e, and $l$

Based on the migrated and redisplayed seismic profiles along Lines 1005 (Fig. 3) and 1027 (Fig. 4), we propose $l$ as an unconformable surface that corresponds to m0.5 at Site 902 (Fig. 5), p5 at Site 


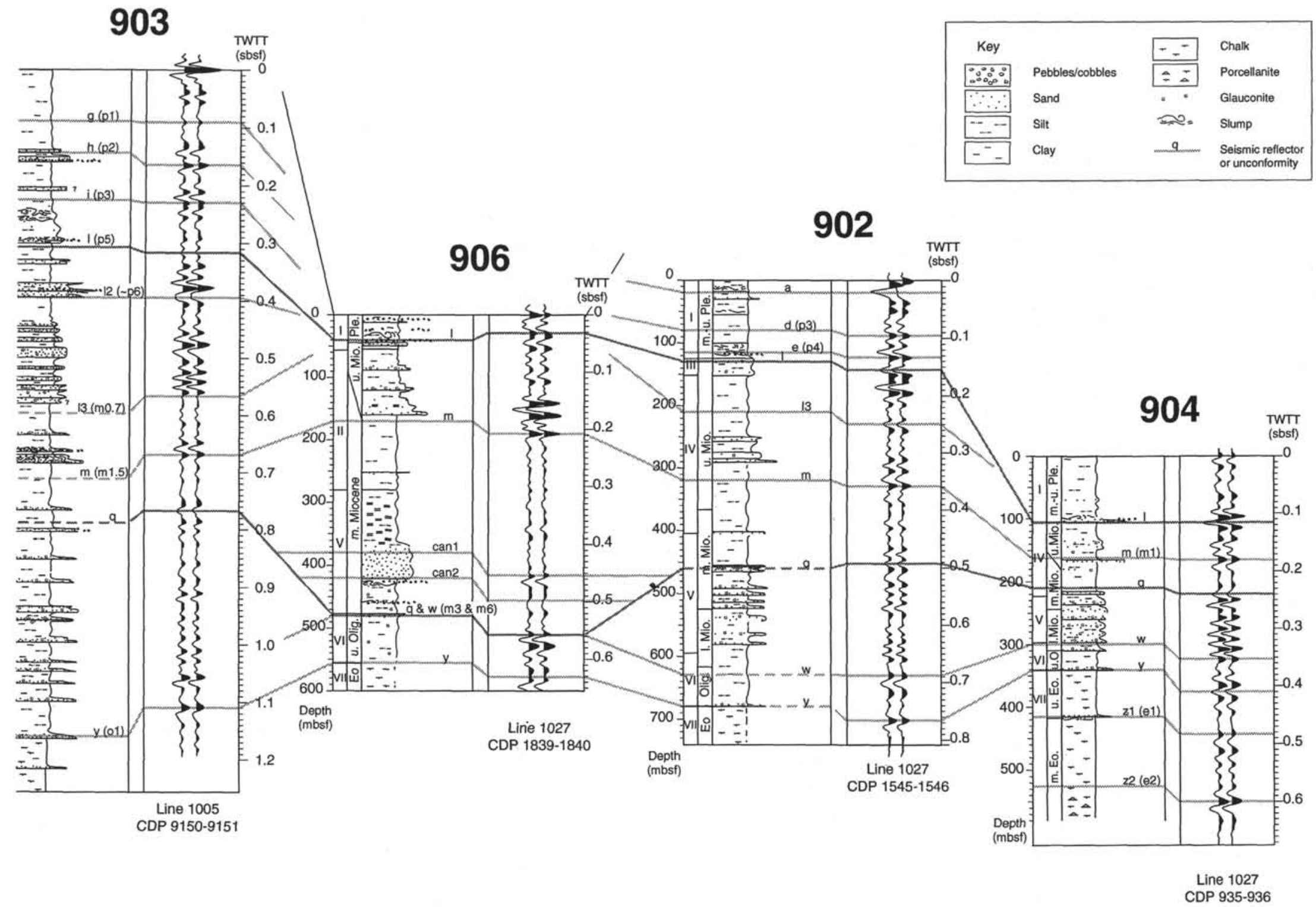

Figure 9. Correlation of reflectors and seismically defined unconformable surfaces along Lines 1005 and 1027 tied to positions in the lithologic columns corresponding to Sites $902,903,904$, and 906 (Mountain, Miller, Blum, et al., 1994). The most prominent erosion surfaces within the study area are shown by a darker shading. Broken lines indicate uncertain correlation with borehole because of poor-quality synthetic seismograms. Reflector labels in parentheses denote equivalent shipboard identifications. Lithologic units and ages are from Mountain, Miller, Blum, et al. (1994). 
903 (Fig. 6), and m0.7 at Site 904 (Fig. 7). This new interpretation simplifies the previous terminology (Mountain, Miller, Blum, et al., 1994) and is possible because the greater vertical exaggeration in the seismic data separates the converging reflectors and shows their terminations more clearly.

Surface $l$ is most noticeable at Site 904 as the base of a relatively high-velocity and high-density "lid" of gravity-driven sediments (Mountain, Miller, Blum, et al., 1994). From the seismic nature and composition of the overlying sediments, $l$ may have been created by slope mass wasting. At Site 902 (Fig. 4), unconformable surfaces a and $\mathrm{d}, \mathrm{e}$, and $l$ subdivide the Pleistocene section into seismic stratigraphically discordant units. Several of these units show internal, contorted, seismic reflector geometries. Surface a truncates two immediately underlying shaded reflectors. These two reflectors (b and c) are marked on the correlation chart for Site 902 (Fig. 5), but they have not been drawn along the seismic profile of Line 1027 (Fig. 4) because they do not appear to be unconformable surfaces. Surface d crowns an internally rotated/slumped unit resting on surface $l$.

\section{Miocene Surfaces $\mathbf{m}$ and $\mathbf{q}$}

Major middle-Miocene unconformities $\mathrm{m}$ and $\mathrm{q}$ stand out in the seismic profiles of Lines 1005 and 1027 (Figs. 3, 4), respectively. Unconformable surfaces $\mathrm{m}$ and $\mathrm{q}$ lie near reflector picks $\mathrm{ml} / \mathrm{ml} .5$ and $\mathrm{m} 2 / \mathrm{m} 3$, which are suspected to have middle Miocene "ages" of about 9-11 and $\sim 13.5 \mathrm{Ma}$, respectively (Mountain, Miller, Blum, et al., 1994; Miller et al., this volume), that may correspond to glacioeustatic sea-level lowerings.

Our interpretation differs from previous shipboard results because it implies that $\mathrm{m}$ is continuous as far as Site 904 . Surface $\mathrm{m}$ is clearly erosional on the sides of a small buried canyon just south of Site 906 . Between this buried canyon and Site 902 , the reflectors at or just below $\mathrm{m}$ are discontinuous and diffractive in character. From the diffractive character near $\mathrm{m}$, we interpret the existence of a possibly rough (eroded?) surface, although similar evidence is absent at Site 904. If surfaces such as $\mathrm{m}$ or $\mathrm{q}$ are the result of a relative sea-level lowering, the sediments above these unconformities would show an increased influence of traction and gravity-flow processes.

At Site 904, we trace surface $m$ from a black peak in the synthetic seismogram into the borehole (Fig. 7), close to the top of a sandy unit (Mountain, Miller, Blum, et al., 1994). This result disagrees with previous models that preferentially correlated reflectors to the base of slumped intervals and coarser grained units (Mountain, Miller, Blum, et al., 1994).

At Site 903 , it is not possible to match surface $m$ by means of the correlation chart to the base of a coarse sandy unit at m1.5 (Mountain, Miller, Blum, et al., 1994). There is no apparent unconformity to which surface $\mathrm{m}$ should correlate below $\mathrm{m} 1.5$. We speculate that the mismatch between surface $\mathrm{m}$ and reflector $\mathrm{ml} .5$ (Mountain, Miller, Blum, et al., 1994) in the borehole could be the result of an imprecision in the shipboard interpretation or inadequate physical properties data in the synthetic seismograms (as noted previously, shipboard physical properties velocity data could not be obtained for Site 903).

Along Lines 1005 and 1027, we draw q as an unconformable canyon-cutting surface. In previous interpretations (Mountain, Miller, Blum, et al., 1994), a reflector $m 3$ was defined to represent the same canyon-cutting surface. However, the expanded seismic displays used in this paper reveal that $\mathrm{m} 3$ lies below surface $\mathrm{q}$ at Sites 902 , 903, and 904 (Figs. 5-7). When correlated to the borehole at Site 904, $\mathrm{q}$ also lies at the top of a coarser grained unit (Mountain, Miller, Blum, et al., 1994).

\section{DISCUSSION}

In this study, we cannot propose to examine exhaustively the global phenomenon of the eustatic origin of observed unconformities be- cause the seismic and borehole data are limited to the middle and upper slope. However, unconformities on the New Jersey continental slope document deep-water (Valentine, 1980) erosive processes that may be indirectly linked to sea-level changes. For example, sea-level lowerings may facilitate delivery of large volumes of sediment that can destabilize slopes and eventually lead to slumping (e.g., Coleman et al., 1983; Kolla and Macurda, 1988). Various other mechanisms of slope incision not necessarily associated with sea-level changes are reviewed in Mountain (1987) and Mountain et al. (1994b).

During the middle Miocene, large deltas (Schlee, 1981; Poag and Mountain, 1987) prograded across the modern continental shelf (Greenlee and Moore, 1988; Steckler et al., 1993). We suggest that at that time the New Jersey margin slope may have been particularly predisposed to the effects of mass wasting because of the increased sediment supply during the middle Miocene. U/Th gamma-ray count values can be used to locate an increase in terrestrial-derived sediments (Rider, 1986; Hesselbo, this volume). At Sites 902 and 904, in the upwell direction, there are marked increases in the estimated total thorium content at about 470 and $230 \mathrm{mbsf}$, respectively. The present-day continental slope is a relatively steep zone ( $\sim 4^{\circ}$ in Fig. 3$)$ where sediment is also prone to movement by gravity-driven processes (Riggs and Belknap, 1988). Seismic evidence for major pre-q canyon-cutting surfaces is limited (Fulthorpe et al., this volume), although some evidence for earlier Cenozoic submarine canyons may have been removed in the Oligocene (Mountain, 1987; Mountain and Tucholke, 1985) by a major erosional event that produced a hiatus across an upper Eocene/upper Oligocene surface (y; this paper).

\section{Unconformities and Coarse-Grained Sediments}

If we accept the shipboard interpretations that unconformities are found at the bottom of coarser grained units, then canyon-cutting surfaces $\mathrm{m}$ and $\mathrm{q}$ should correlate to the base of sandy sedimentary units in the borehole. The fact that at Site $904 \mathrm{~m}$ and $\mathrm{q}$ lie toward the top of the same units suggests various alternatives. First, these surfaces may actually mark a canyon-cutting unconformity near the top of the coarser grained units. Our interpretation suggests that the more regressive sandier units are deposited before the canyon surface is cut. Canyon-cutting could be initiated by failing slopes (Farre et al., 1983; Mountain, 1987) after a short period of sediment buildup and, therefore, could lag behind the greatest rates of sea-level fall.

As a second interpretation, surface $\mathrm{q}$ would have to be picked deeper in the section (e.g., 50 ms deeper at Site 904; Fig. 4) near a surface of apparent downlap. However, we prefer the first interpretation along Line 1027 (Fig. 4) because q divides underlying truncated reflectors from overlying continuous or onlapping reflectors (e.g., near Sites 906 and 904). Coincidentally, q also separates distinct seismic facies. Immediately below q, the seismic facies consists of distinctive high-amplitude continuous reflectors and above q they are of lower relative amplitude, although these relationships are less evident along Line 1005 (Fig. 3).

\section{Strength of Reflections}

Once calibrated to borehole data, the distinguishing characteristics of seismic reflections (seismic facies) can act as proxies for the environment of deposition and sediment composition (Mitchum et al., 1977). Throughout the Neogene, clastic sediment bodies on this old continental passive margin were highly progradational because the accommodation space was small as a result of low thermal subsidence rates (Greenlee et al., 1992). Along the profile of Line 1027 (Fig. 4), the internal seismic facies of the sequence bounded by erosional surfaces $q$ and $w$ belongs to the distal toes of prograding clinoforms. The internal reflectors are different from the facies in the units immediately above and below because of their greater amplitude and lateral continuity among Sites 902, 904, and 906. At Site 904, the high-amplitude black reflectors (e.g., dashed correlation lines in Fig. 
7) tie to glauconite-rich silty sand intervals. The acoustic impedance contrast between the glauconite-rich sands and the intervening biogenic, glauconite-poor silty clays gives rise to strong reflections. Lower amplitude reflectors appear in the upper-middle Miocene interval above $\mathrm{q}$ because the sediments are acoustically more homogeneous.

\section{Correlation Between Shelf/Slope Horizons}

Seismic correlation between the shelf and slope is made difficult by stratigraphic units and reflectors that converge seaward (Thorne, 1992). Ideally, when downlapping reflectors terminate, we expect them to merge into a single reflector. In practice, however, as observed near Site 904 just above surface y (Oligocene/Eocene disconformity), reflectors do not terminate but converge to produce a set of parallel reflectors within a zone of downlap. With the aid of borehole data and synthetic seismograms, we interpret that the pair of parallel reflectors comprising y near Site 904 is generated by the summed reflections from the top and bottom of a thin $(<10 \mathrm{~m})$ glauconitic sandy silty clay unit (Fig. 4). The bottom of this unit is surface $y$, the upper Eocene-upper Oligocene unconformity. These two reflectors diverge toward the shelf; near Site 906 , they are about $50 \mathrm{~ms}$ apart on the seismic profile (Fig. 4), below the Oligocene/Miocene boundary (surface w). It appears that surface y, an unconformity, is a surface of downlap, because the sandy unit below w pinches out.

\section{Diagenetic Boundaries}

Diagenetic fronts can create sharp changes in physical properties resulting in reflectors such as $\mathrm{z} 2$. Downhole through this front, there is a generally marked increase in the acoustic impedance, in association with a marked reduction in porosity as bioclastic silica (opal-A) is reprecipitated as interstitial cement (opal-CT) (e.g., Weaver and Wise, 1974; Riech and von Rad, 1979; Wilkens et al., 1987). In sequence stratigraphy, seismic reflections are usually produced along bedding surfaces and unconformities (Vail et al., 1977) and are significant chronostratigraphically. As a diagenetic surface, $\mathrm{z} 2$ might be diachronous. Drilling has shown that this surface varies in age from late-early to early-middle Eocene in the deep basin (Tucholke and Vogt, 1979), on the slope (Poag, Watts, et al., 1987), and onshore (Miller et al., 1990, 1994). Although reflectors appear to onlap z2 along Line 1027 (Fig. 4), interpretations of z2 should not be based only on its relationship to other seismic events because of the possibility that its origin is diagenetic. During DSDP Leg 95, Goldberg et al. (1987) noted that physical properties changes down through this silica-diagenetic front could vary between sites. Together, DSDP Sites 603, 605, 612, and 613 and ODP Site 904, each located successively landward, show a systematic increase in the degree of induration across this diagenetic front as indicated by the degree to which physical properties change. At Site 904, the front is composed of a high-velocity and high-density layer atop porcellanite, similar to that observed at the slope Site 612, but distinct from the gradational front described for Site 613. Actually, the downhole increase in density across the front at Site $904\left(\sim 25 \%, \sim 2.0-2.5 \mathrm{~g} / \mathrm{cm}^{3}\right)$ is approximately double that modeled for Site $612\left(\sim 8 \%, 1.8-1.95 \mathrm{~g} / \mathrm{cm}^{3}\right)$. Induration can be retarded by other factors (e.g., see McHugh et al., 1993) such as the abundance of clay observed at Site 603 on the continental rise where no silica front was found (Thein and von Rad, 1987). Unexpectedly, the amplitude along reflector z2 decays (Fig. 4) near the COST B-3 site. Initial results from drilling at COST B-3 (Scholle, 1980) do not emphasize the presence of the porcellanites, although there is a sharp downhole increase in the compressional-wave velocity of sediments at the upper Eocene boundary (Taylor and Anderson, 1980). Porcellanites have been described in middle Eocene chalks onshore in the Manasquan Formation (Miller et al., 1990, 1994). If reflection strength is a measure of the degree of silica diagenesis in the chalk sediments, then we would speculate that the abundance of Eocene porcellanites decreases within our study area north of Site COST B-3, a distance about $9 \mathrm{~km}$ farther landward than previously mapped (Sheridan and Grow, 1988, pl. 3). Silica-rich sediments are persistent from onshore to the abyss (Mountain and Tucholke, 1985) although our data set suggests changes in the impedance contrast across the silica-diagenetic front.

\section{CONCLUSIONS}

Seismic-to-borehole correlation at Leg 150 sites was conducted by combining downhole and shipboard laboratory physical properties measurements to calculate synthetic seismograms. Downhole properties have the advantage of being collected in situ, free of rebound effects and gas expansion, but they are subject to borehole stability and so cannot always provide a continuous suite of measurements. Sites 904 and 906 provide the best quality downhole and shipboard physical properties data sets and hence the most robust correlation. Synthetic seismograms at Site 902 could only be generated from shipboard physical properties. Site 903 seismic-well correlations are tentative at midhole depths.

Multichannel, tuned, air-gun, seismic data contain less noise than the single-channel, water-gun data and are more suitable for sequence stratigraphic interpretation. Constant velocity migration and profiles displayed at an increased vertical exaggeration greatly improve our ability to resolve seismic unconformities. With the aid of this seismic data, unconformities $\mathrm{m}$ and $\mathrm{q}$, major middle-Miocene canyon-cutting surfaces, correlate to the top of coarser grained lithologic units. We suggest that these canyon-cutting events may have lagged slightly behind a short period of terrestrial sediment buildup on the slope. Surface $l$ may correspond to a major Miocene-Pleistocene slump surface. Future work is needed to refine the relationships between lithologic facies and canyon-cutting surfaces.

When compressional-wave velocity and wet-bulk density values are of good quality, seismic facies can be reproduced using synthetic seismograms, even using a simple one-dimensional linear filter approach. At Site 904, a high-amplitude continuous seismic facies between unconformities $q$ and $w$ can be attributed to distal toe-of-clinoform alternating glauconite-rich and glauconite-poor sedimentary facies. This facies prediction remains to be confirmed at other locations.

Diagenetic fronts in the subsurface can produce diachronous reflectors. The seismic character of diagenetic fronts and the relative degree of induration across the middle Eocene silica diagenetic front can potentially be inferred and mapped in three-dimensions.

\section{ACKNOWLEDGMENTS}

This study was supported by USSSP Account No. 150-20785b. We are grateful for the valuable time and effort given by many colleagues as this paper was developed. G. Mountain, K. Miller, and C. Fulthorpe reviewed early versions of the manuscript and provided many useful suggestions. The final version of this manuscript improved markedly thanks to the insightful reviews of D. Hutchinson and N. Bangs.

\section{REFERENCES}

Coleman, J.M., Prior, D.B., and Lindsay, J.F., 1983. Deltaic influences on shelf-edge instability processes. In Stanley, D.J., Moore, G.T. (Eds.), The Shelf Break: Critical Interface on Continental Margins. Spec. Publ.Soc. Econ. Paleontol. Mineral., 33:121-137.

Edgar, N.T., Saunders, J.B., et al., 1973. Appendix I. In Edgar, N.T., Saunders, J.B., et al., Init. Repts. DSDP, 15: Washington (U.S. Govt. Printing Office), 1115-1128. 
Farre, J.A., McGregor, B.A., Ryan, W.B.F., and Robb, J.M., 1983. Breaching the shelfbreak: passage from youthful to mature phase in submarine canyon evolution. In Stanley, D.J., and Moore, G.T. (Eds.), The Shelfbreak: Critical Interface on Continental Margins. Spec. Publ.-Soc. Econ. Paleontol. Mineral., 33:25-39.

Fischer, A.G., 1984. Two Phanerozoic supercycles. In Berggren, W.A., and Van Couvering, J.A. (Eds.), Catastrophes and Earth History: Princeton, NJ (Princeton Univ. Press), 129-150.

Goldberg, D., Wilkens, R.H., and Moos, D., 1987. Seismic modeling of diagenetic effects in Cenozoic marine sediments at Deep Sea Drilling Project Sites 612 and 613. In Poag, C.W., Watts, A.B., et al., Init. Repts. DSDP, 95: Washington (U.S. Govt. Printing Office), 589-599.

Greenlee, S.M., Devlin, W.J., Miller, K.G., Mountain, G.S., and Flemings, P.B., 1992. Integrated sequence stratigraphy of Neogene deposits, New Jersey continental shelf and slope: comparison with the Exxon model. Geol. Soc. Am. Bull., 104:1403-1411.

Greenlee, S.M., and Moore, T.C., 1988. Recognition and interpretation of depositional sequences and calculation of sea level changes from stratigraphic data-offshore New Jersey and Alabama Tertiary. In Wilgus, C.K., Posamentier, H., Ross, C.A., and Kendall, C.G.St.C. (Eds.), SeaLevel Changes: An Integrated Approach. Spec. Publ.-Soc. Econ. Paleontol. Mineral., 42:329-353.

Hamilton, E.L., 1976. Variations of density and porosity with depth in deepsea sediments. J. Sediment. Petrol., 46:280-300.

Haq, B.U., Hardenbol, J., and Vail, P.R., 1987. Chronology of fluctuating sea levels since the Triassic. Science, 235:1156-1167.

Kolla, V., and Macurda, D.B., 1988. Sea-level changes and the timing of turbidity: current events in deep-sea fan sediments. In Wilgus, C.K., Hastings, B.S., Kendall, C.G., Posamentier, H.W., Ross, C.A., and Van Wagoner, J.C. (Eds.), Sea-Level Changes: An Integrated Approach. Spec. Publ.-Soc. Econ. Paleontol. Mineral., 42:381-392.

LASE Study Group, 1986. Deep structure of the US East Coast passive margin from large aperture seismic experiments (LASE). Mar. Pet. Geol, $3: 234-242$.

Mayer, L., Pisias, N., Janecek, T., et al., 1992. Proc. ODP, Init. Repts., 138: (Pts. 1 and 2): College Station, TX (Ocean Drilling Program).

Mayne, W.H., 1962. Common reflection point horizontal stacking techniques. Geophysics, 27:927-938.

McHugh, C.M., Ryan, W.B.F., and Schreiber, B.C., 1993. The role of diagenesis in exfoliation of submarine canyons. AAPG Bull., 77:145172.

Miller, K.G., et al., 1994. Proc. ODP, Init. Repts., 150X: College Station, TX (Ocean Drilling Program).

Miller, K.G., Kent, D.V., Brower, A.N., Bybell, L.M., Feigenson, M.D., Olsson, R.K., and Poore, R.Z., 1990. Eocene-Oligocene sea-level changes on the New Jersey coastal plain linked to the deep-sea record. Geol. Soc. Am. Bull., 102:331-339.

Miller, K.G., Melillo, A.J., Mountain, G.S., Farre, J.A., and Poag, C.W., 1987. Middle to late Miocene canyon cutting on the New Jersey continental slope: biostratigraphic and seismic stratigraphic evidence. Geology, 15:509-512.

Miller, K.G., Wright, J.D., and Fairbanks, R.G., 1991. Unlocking the Ice House: Oligocene-Miocene oxygen isotopes, eustasy, and margin erosion. J. Geophys. Res., 96:6829-6848.

Mitchum, R.M., Jr., Vail, P.R., and Sangree, J.B., 1977. Seismic stratigraphy and global changes of sea level, Part 6. Stratigraphic interpretation of seismic reflection patterns in depostional sequences. In Payton, C.E. (Ed.), Seismic Stratigraphy: Applications to Hydrocarbon Exploration. AAPG Mem., 26:117-133.

Mitchum, R.M., Jr., Vail, P.R., and Thompson, S., III, 1977. Seismic stratigraphy and global changes of sea level, Part 2 . The depositional sequence as a basic unit for stratigraphic analysis. In Payton, C.E. (Ed.), Seismic Stratigraphy: Applications to Hydrocarbon Exploration. AAPG Mem., 26:53-62.

Mountain, G.S., 1987. Cenozoic margin construction and destruction offshore New Jersey. In Ross, C., and Haman, D. (Eds.), Timing and Depositional History of Eustatic Sequences: Constraints on Seismic Stratigraphy. Spec. Publ. Cushman Found. Foraminiferal Res., 24:5783.

Mountain, G.S., Lorenzo, J.M., and Fulthorpe, C.S., 1994a. Underway geophysics. In Mountain, G.S., Miller, K.G., Blum, P., et al., Proc. ODP, Init. Repts., 150: College Station, TX (Ocean Drilling Program), 43-50.

Mountain, G.S., Miller, K.G., Blum, P., et al., 1994. Proc. ODP, Init. Repts., 150: College Station, TX (Ocean Drilling Program).
Mountain, G.S., Miller, K.G., and the Leg 150 Scientific Party, 1994b. Sealevel and slope processes reflected off New Jersey. Eos, 75:212-214.

Mountain, G.S., and Tucholke, B.E., 1985. Mesozoic and Cenozoic geology of the U.S. Atlantic continental slope and rise. In Poag, C.W. (Ed.), Geologic Evolution of the United States Atlantic Margin: New York (Van Nostrand Reinhold), 293-341.

Parkes, G., and Hatton, L., 1986. The Marine Seismic Source: Dordrecht (D. Reidel).

Peterson, R.A., Fillipone, W.R., and Coker, E.B., 1955. The synthesis of seismograms from well log data. Geophysics, 20:516-538.

Poag, C.W., 1985. Depositional history and stratigraphic reference section for central Baltimore Canyon trough. In Poag, C.W. (Ed.), Geologic Evolution of the United States Atlantic Margin: New York (Van Nostrand Reinhold), 217-263.

Poag, C.W., and Mountain, G.S., 1987. Late Cretaceous and Cenozoic evolution of the New Jersey continental slope and upper rise: an integration of borehole data with seismic reflection profiles. In Poag, C.W., Watts, A.B., et al., Init. Repts. DSDP, 95: Washington (U.S. Govt. Printing Office), 673-724.

Poag, C.W., Watts, A.B., et al., 1987. Init. Repts. DSDP, 95: Washington (U.S. Govt. Printing Office).

Rider, M.H., 1986. The Geologic Interpretation of Well Logs: London (Blackie/Halsted Press).

Riech, V., and von Rad, U., 1979. Eocene porcellanites and early Cretaceous cherts from the Western North Atlantic. In Tucholke, B.E., Vogt, P.R., et al., Init. Repts. DSDP, 43: Washington (U.S. Govt. Printing Office), 437-448.

Riggs, S.R., and Belknap, D.F., 1988. Upper Cenozoic processes and environments of continental margin sedimentation: eastern United States. In Sheridan, R.E., and Grow, J.A. (Eds.), The Atlantic Continental Margin. Geol. Soc. Am., 131-176.

Robinson, E.A., 1970. Statistically optimal stacking of seismic data. Geophysics, 35:436-446.

Schlee, J.S., 1981. Seismic stratigraphy of Baltimore Canyon Trough. AAPG Bull., 65:26-53.

Schlee, J.S., Manspeizer, W., and Riggs, S.R., 1988. Paleoenvironments: offshore Atlantic U.S. margin. In Sheridan, R.E., and Grow, J.A. (Eds.), The Atlantic Continental Margin: U.S. Geol. Soc. Am., Geol. of North Am. Ser., 1-2:365-385.

Scholle, P.A. (Ed.), 1980. Geological studies of the COST No. B-3 well, United States mid-Atlantic continental slope area. Geol. Surv. Circ. (U.S.), 833.

Sengbush, R.L., 1983. Seismic Exploration Methods: Boston (Int. Human Res. Dev. Corp.).

Sheridan, R.E., and Grow, J.A., 1988. The Atlantic Continental Margin: U.S. Geol. Soc. Am., Geol. of North Am. Ser., I-2.

Sheriff, R.E., 1977. Limitations on resolution of seismic reflections and geologic detail derivable from them. In Payton C.E. (Ed.), Seismic Stratigraphy: Applications to Hydrocarbon Exploration. AAPG Mem., 26:3-14.

Steckler, M.S., Reynolds, D.J., Coakley, B.J., Swift, B.A., and Jarrard, R., 1993. Modelling passive margin sequence stratigraphy. In Posamentier, H.W., Summerhayes, C.P., Haq. B.U., and Allen, G.P. (Eds.), Sequence Stratigraphy and Facies Associations. Spec. Publ. Int. Assoc. Sedimentol., 18:19-41.

Taylor, D.J., and Anderson, R.C., 1980. Geophysical studies. In Scholle, P.A. (Ed.), Geological Studies of the COST No. B-3 Well, United States Mid-Atlantic Continental Slope Area. Geol. Surv. Circ. (U.S.), 833:105110.

Thein, J., and von Rad, U., 1987. Silica diagenesis in continental rise and slope sediments off eastern North America (Sites 603 and 605, Leg 93; Sites 612 and 614, Leg 95). In Poag, C.W., Watts, A.B., et al., Init. Repts. DSDP, 95: Washington (U.S. Govt. Printing Office), 501-525.

Thorne, J.A., 1992. An analysis of the implicit assumptions of the methodology of seismic sequence stratigraphy. In Watkins, J.S., Zhiqiang, F., and McMillen, K.J. (Eds.), Geology and Geophysics of Continental Margins. AAPG Mem., 53:375-394.

Tucholke, B.E., and Mountain, G.S., 1979. Seismic stratigraphy, lithostratigraphy, and paleosedimentation patterns in the North American basin. In Talwani, M., Hay, W., and Ryan, W. (Eds.), Deep Drilling Results in the Atlantic Ocean: Continental Margins and Paleoenvironment. Am. Geophys. Union, Maurice Ewing Ser., 3:58-86.

Tucholke, B.E., and Vogt, P.R., 1979. Western North Atlantic: sedimentary evolution and aspects of tectonic history. In Tucholke, B.E., Vogt, P.R., et al., Init. Repts. DSDP, 43: Washington (U.S. Govt. Printing Office), 791-825. 
Vail, P.R., Todd, R.G., and Sangree, J.B., 1977. Seismic stratigraphy and global changes of sea level, Part 5. Chronostratigraphic significance of seismic reflections. In Payton, C.E. (Ed.), Seismic Stratigraphy: Applications to Hydrocarbon Exploration. AAPG Mem., 26:99-116.

Valentine, P.C., 1980. Calcareous nannofossil biostratigraphy, paleoenvironments, and post-Jurassic continental margin development. In Scholle, P.A. (Ed.), Geological Studies of the COST No. B-3 Well, United States Mid-Atlantic Continental Slope Area. Geol. Surv. Circ. (U.S.), 833:6783.

Weaver, F.M., and Wise, S.W., Jr., 1974. Opaline sediments of the southeastern coastal plain and Horizon A: biogenic origin. Science, 184:899901.
Widess, M.B., 1973. How thin is a thin bed? Geophysics, 38:1176-1180.

Wilkens, R.H., Schreiber, B.C., Caruso, L., and Simmons, G., 1987. The effects of diagenesis on the microstructure of Eocene sediments bordering the Baltimore Canyon Trough. In Poag, C.W., Watts, A.B., et al., Init. Repts. DSDP, 95: Washington (U.S. Govt. Printing Office), 527-547.

Date of initial receipt: 6 March 1995

Date of acceptance: 20 December 1995

Ms 150SR-031 